Original Research Paper

\title{
Land-Cover Removal and Gully Development in Southeast Nigeria: A 30-Year Analysis with Pixel and OBIA Approaches in Juxtaposition
}

\author{
Sylvanus Iro \\ Geography and Environmental Management, Imo State University, Owerri Nigeria, Nigeria
}

Article history

Received: 03-03-2020

Revised: 05-05-2020

Accepted: 08-06-2020

Email: sylvanusiro@gmail.com

\begin{abstract}
In this study a study of gully erosion in southeast Nigeria is presented. The study of gully development on a regional scale is currently undermined by the inherent costs associated with consistent field monitoring and the lack of historic measurements to perform time series analysis. As a result, there are very few studies which implement long term analyses of gullies in the region as a collective. Consequently, the building of knowledge of the role of environmental changes on the development of gullies is inhibited. Remote sensing methodologies, via the Landsat archive, are used as low economic data source that assisted in the analyses of gullies over the time period 1986 to 2015 . The Landsat data is used to establish land cover changes over the time period, via pixel and object-based classification, to identify its role in gully development. The use of classification for this purpose identifies this study as a first of its kind in Nigeria. Aiming to link environmental characteristics and land cover changes with gully development and erosion rates at multiple current locations. In terms of the correlation between vegetation area and gully/openland development, Pixel based classification produced a correlation of $\mathrm{r}=-0.9(p<0.05)$. A similar strength of correlation was exhibited for OBIA with $\mathrm{r}=-0.9(p<0.05)$ with both results indicating a very strong and significant negative correlation between the amount of vegetated area and Gully/open-land development over the study period 1986-2015.
\end{abstract}

Keywords: Land-Cover, Gully Erosion, Pixel and OBIA Classification

\section{Introduction}

Gully erosion has been recognized as one of the major causes of land degradation worldwide (Valentin et al., 2005). Gully erosion has attracted a growing interest as reflected by some international conferences at Leuven, Belgium (Poesen and Valentin, 2003), at Chengdu, China (Li et al., 2004) and Purdue University in West Lafayette, Indiana, USA, May,2016. Some recent research works (Wu and Cheng, 2005; Onyekwere, 2001; Castillo and Gomez, 2016) have shown that the loess plateau of China, Orlu Nigeria and Cordoba, Spain land surfaces are being eroded, washed away and rendered sterile due to gully erosion. Gully erosion has been a growing concern to mainly the developing world which could be due to both intentional and unintentional activities of humans on the physical environment (Duke, 2012). In southeast Nigeria, gully development has become one of the greatest environmental hazards in many villages and towns (Ezezika and Adetona, 2011). Ofomata observed that about $2 \%$ of the area is fast becoming hazardous to human habitation because of gully formation and subsequent degradation in the area (Obiadi et al., 2011).

Unfortunately, according to (Igbozurike, 2010) about 5000 people are directly or indirectly affected by this, causing forced relocation from ancestral homes every year, as can be found in Nanka-Agulu and Onitsha southeast Nigeria observed in Fig. 1 above. About 12\% of agricultural lands are becoming unsuitable for cultivation as gully erosion destroys farmlands and lowers agricultural productivity through removal of essential topsoil (Egboka, 1993). The formation of gully erosion and sediments are a function of rainfall, soil properties and topography and can be induced by human interference including land management practices. The rainfall intensity is high in this area of Nigeria and often persists for long durations. Storms with over $25 \mathrm{~mm} / \mathrm{h}$ 
intensity have been reported by Hudson to be particularly erosive (Igwe, 2005). Igwe (2005) observed in the region that most gullies develop at slopes, cuestas, fractures and joints which are common features in the gully-erosion-prone areas of Southeast Nigeria and have been identified as significant factors in the formation of gullies and subsequent erosion. The study area has also seen increased erosion rates through the exacerbating effect of mineral extraction sites (Gao et al., 2007; Okoro and Nweke, 2013). The loss of soil degrades arable land and eventually renders it unproductive. As a result, there are significant per capita shortages of arable land. The effects of this erosive action are made more severe by recent and rapid population growth in the Southeast region of Nigeria. Loss of agricultural output is one of the greatest economic costs of gully erosion (Posser and Slade, 1994). Unquantified large portions of land have been degraded in recent years in towns such as Ekwulobia, Agulu-Nanka, Orlu, Iyioku, Njaba, Igboukwu, Okigwe, Abiriba, Mbaise, Uturu, Ideato, Amucha. In addition, infrastructure and in particular roads, have been damaged, leading to numerous vehicle accidents and displacement of residential houses. A number of studies have been conducted on the causes of gully erosion in Southeast Nigeria and ways to control them. Most of the studies primarily revolve around causes based on the immediate scenario rather than the long term causes as can be found in (Madu et al., 2006; Ezezika and Adetona, 2011). They also deal more with combating gully erosion rather than its prevention and pay little attention to methods of managing this natural hazard.

\section{Study Area}

Gully Erosion occurs in numerous areas within the South-East states of Nigeria. Erosion problems arise mainly from natural causes, but their extent and severity are increasingly attributed to anthropogenic ignorance and unintentional action (Chigbu et al., 2011). In spite of technological advancement including land-use planning (Vrieling et al., 2007), run-off catch pits (Igbozurike, 2010) and drainage channels (Nyom, 2005), gully erosion still remains a major problem in the region. The academic community has observed that gully erosion, is largely a result of natural factors including rainfall run-off (Okoro and Nweke, 2013) and the geological (Posser and Slade, 1994) and geomorphological (Blaschke, 2010) context of the area. There is further agreement that these naturally occurring conditions are prime for gully erosion but are exacerbated by anthropogenic factors such as land-use change and degradation (Vrieling et al., 2007). Each of these occurrences act as push factors in causing gully erosion (Egboka, 1993).

The study area is located in south-east Nigeria between $7^{\circ} 8^{\prime} \mathrm{N} 6^{\circ} 34^{\prime} \mathrm{E}$ and $4^{\circ} 49^{\prime} \mathrm{N} 8^{\circ} 15^{\prime} \mathrm{E}$ covering a land area of approximately $57,758.034 \mathrm{Km}^{2}$, as shown in Fig. 2 and 3. It is characterised by coexisting types of land use and land cover, which are mainly affected by gully erosion.

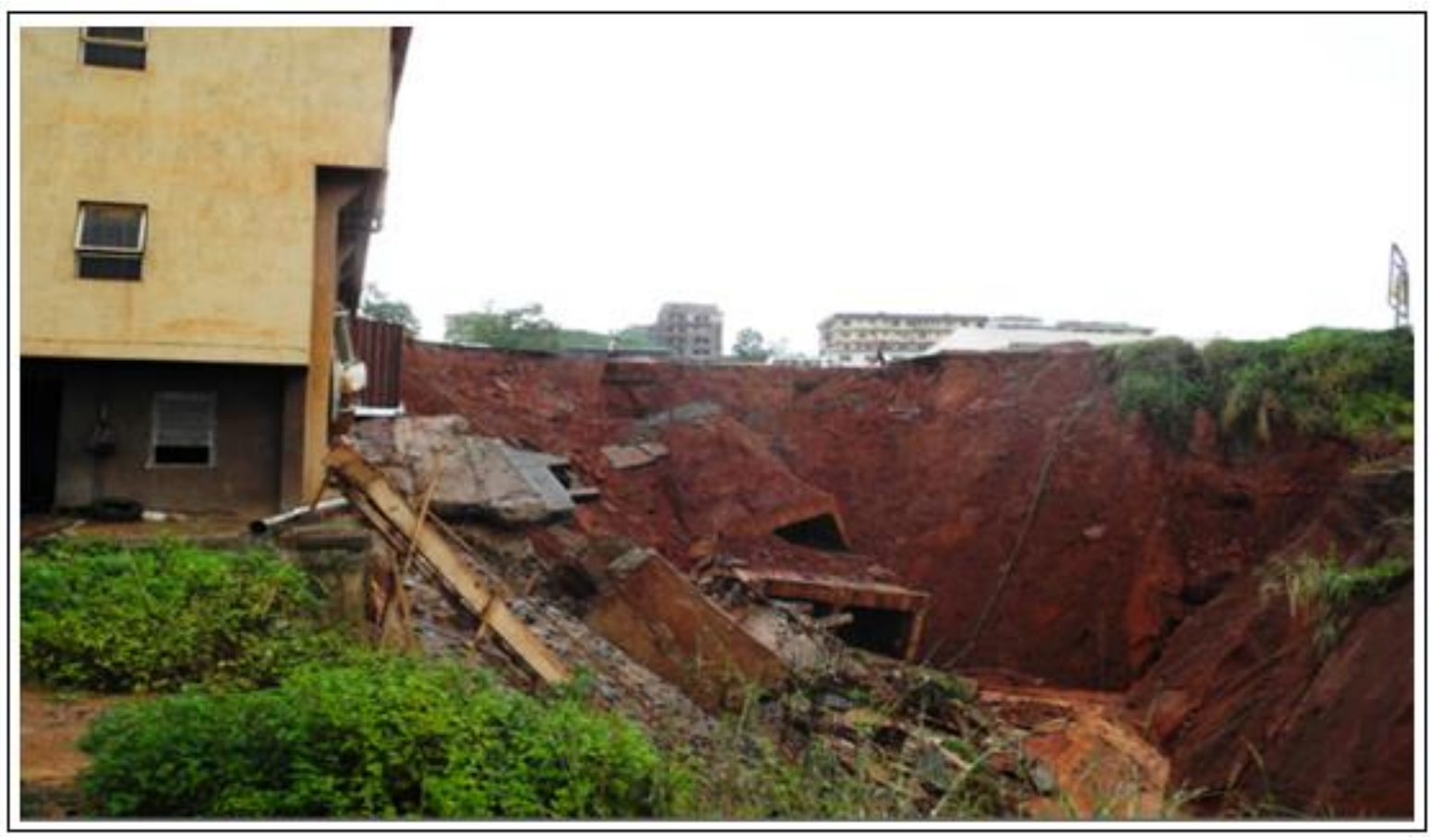

Fig. 1: Gully erosion in Onitsha southeast Nigeria (Abdulfatai et al., 2014) 


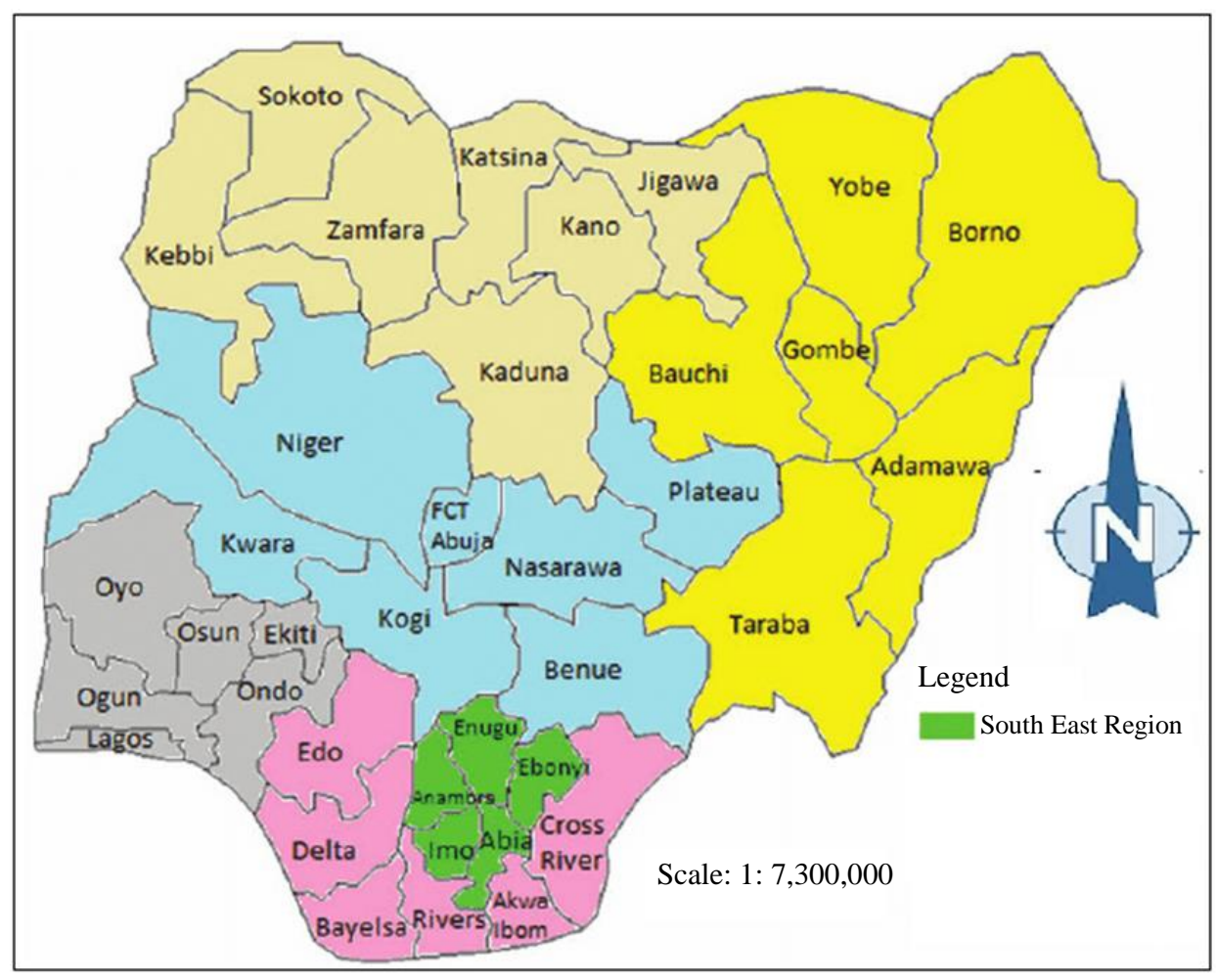

Fig. 2: Nigeria with the Study area outlined for context (Gayawan et al., 2014)

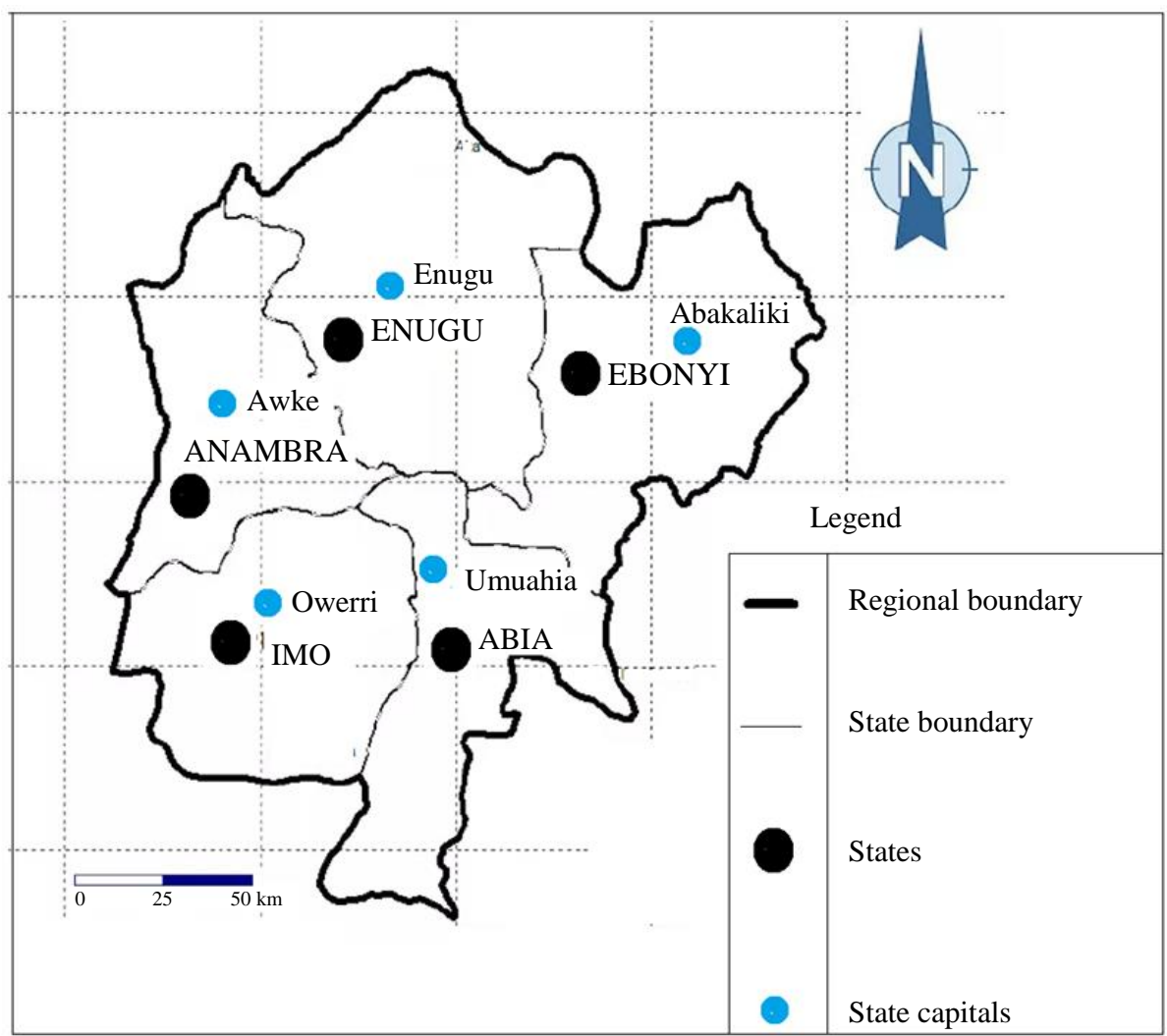

Fig. 3: Map of south-east Nigeria showing the states and their capitals (Okonkwo, 2014) 
The study area lies within the humid tropical rainforest belt with an annual rainfall of approximately 1800-3000 mm (Aigbedion and Iyayi, 2007). Vegetation in the area is controlled by topography (which varies mainly from flat to swamp like regions), relief and lithology, with anthropogenic factors such as abandoned industrial sites also playing a defining role (Igwe, 2005). The vegetation ranges from rainforest to Guinea Savannah (Ijeoma and Okey, 2005). Dense vegetation with high trees is prominent around streams and shaley lowlands while guinea vegetation and isolated trees are prominent on sandy soils in highland areas (Obiadi et al., 2011). The tropical soil of the area supports extensive plantation forests, such as Oil palm, Rubber, Cocoa and Bananas (Elmahboub et al., 2009). Human activities such as bush burning, agriculture and construction works have greatly modified the natural vegetation in the area, potentially contributing to the creation and extent of gullies (Rozenstein and Karniel, 2011). The Anambra and Enugu basins are the areas most affected by gully erosion (Onyekwere, 2001), an example of this can be seen in Fig. 1. Most of the gullies develop on areas with valley topography rather than areas with flat land (Obiadi et al., 2011). The region is highly dynamic with regards to exploitation and extraction of mineral resources, agriculture, urban growth and wood logging which create high pressure on arable land (Ijeoma and Okey, 2005). The tropical climatic conditions in combination with the deep porous and clayey soils effectively combine to foster the development of gully erosion (Madu et al., 2006). Gully erosion may therefore be considered a direct threat to the non-rural population, as well as to farmers.

Research work and other gully studies such as (Ezezika and Adetona, 2011) in the area have revealed that the causative factors of gully erosion in the area can be traced to both physical/natural and anthropogenic factors. With the highest rainfall average of $3000 \mathrm{~mm}$ from March to November, erosion results from impacts of rain drops on the topographic surface (Igwe, 2005). Similar cases of exacerbation of gully erosion caused by human activities, rather than natural occurrences, abound in parts of the area. Good examples are those of the Ajali water scheme at Owa, the Enugu-Onitsha highway, the Umuchiana gullies at Ekwulobia, the gullies along the Umuchu-Umunze Road, Iyioku gully, Njaba and AguluNanka gullies. Urbanization involving road construction, building developments and other similar activities, contribute immensely to gully development in the zone (Obiadi et al., 2011). Resource extraction processes such as sand excavations and illegal solid mineral mining are also being carried out in this area with a detrimental effect on the landscape. In areas around Emekuku, Njaba of Imo State and Owerrenta in Abia state, people have illegally acquired the permission to excavate sands. Their activities are greatly contributing to gully development.

\section{Rationale of the Study}

The devastation caused by gully erosion in southeast Nigeria is very poorly quantified, in spite of a series of studies carried out by researchers. What is required is a method allowing a regional to national analysis which can be obtained through the use of low-cost medium resolution remote sensing data as proposed in this thesis. Understanding the development and dynamics of major gully sites through the methods proposed in this study will also allow preventative measures to be enacted to reduce the need for future intervention. This gully preventive measures will be nipped in the board when gully development and change over time have been well understood. The problems associated with gully erosion are immense and include; loss of life and houses, infrastructural collapse and loss of agricultural land. The extent, role and development of gullying in the studied region remains unmapped, unabated and unresolved.

\section{Methodology}

\section{Land-cover Classification of the Study Area}

Land cover classifications were deduced from Landsat and ALOS raster data by ISO Cluster Analysis, a form of unsupervised classification for pixel oriented and supervised for OBIA oriented. The ISO Cluster algorithm is a repetitive process for computing the minimum Euclidean distance when allocating each candidate cell to a cluster. The process starts with casual (arbitrary) means being assigned by the software, one for each cluster (the number of clusters will be dictated by the analyst) (Vrieling et al., 2007). ISO Cluster Analysis was chosen because the algorithm separates all cells into the user-specified number of distinct unimodal groups in the multidimensional space of a multiband raster. Also, to provide the sufficient statistics necessary to generate a signature file for better classification (Oltmanns et al., 2014).

These unsupervised and supervised classifications were assisted using the 40 gully points and 60 other land-use points picked during field work. Five classes were chosen to represent the land based on the Landcover types of the study area. The classes identified were 1. Water, 2. Vegetation, 3. Agriculture, 4. Urban-Land and 5 Gully/Open-Land. Accuracy Assessment was done with Google Earth to extract 100 KLM points from the classified data which gave between $80 \%$ to $93 \%$ accuracy. This was checked with the 100 Random points extracted from the classified data; at the location of each random point, a land-cover of that part using GoogleEarth was used to compare it with the land-cover of the classified raster. Google-Earth was used because it has better resolution than Landsat image and the features can be better observed (Virginia, 2011). 


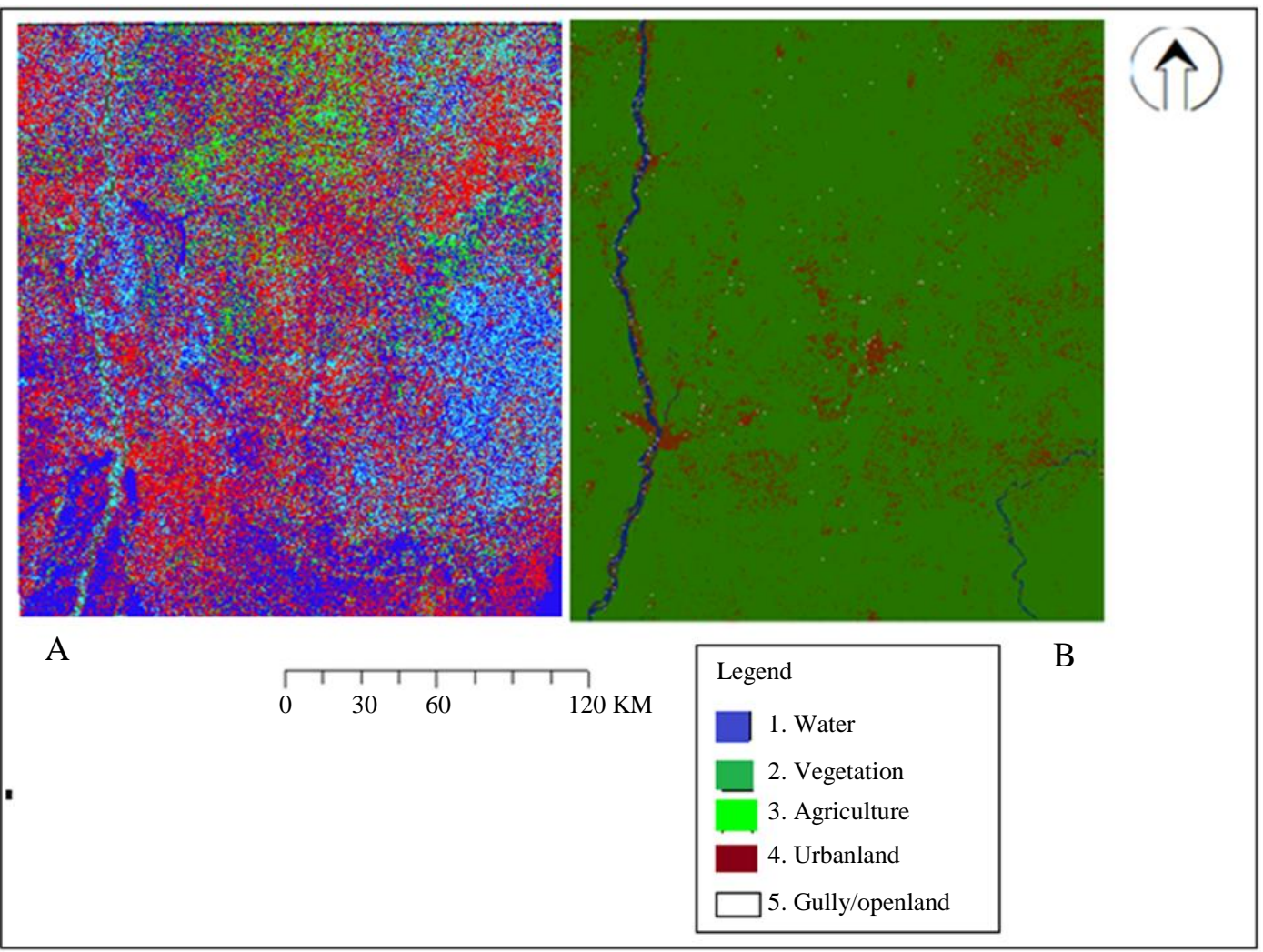

Fig. 4: Example of (a) Landsat 2009 Cluster unsupervised classification of the study area (the different colours represent various Identified spectral values of the pixels) and (b) Example of the result of Reclassified images of Landsat 2009 images of the study area. (Vegetation class is dominant, but when expanded on a GIS software the hidden classes can be clearly observed)

The missing Landsat data from 1994-1999 were obtained by calculating the linear interpolation by connecting two adjacent known values of 1994 and 1999. The Linear Interpolation method used here is shown in equation (Aigbedion and Iyayi, 2007) to estimate the value of a function between two known values. This method allowed land use changes to be classified with respect to time. This method was also used to obtain values for missing data during the vectorization and quantification of the specifically observed gully sites. Linear Interpolation is a method used to determine a present or future value factor when the exact factor does not appear in either a present or future value table. Linear Interpolation assumes that the change between two values is linear and that the margin of error is insignificant. Although the fluctuations in data are not shown to follow an exact linear pattern over the course of the study a linear relationship best fits the data and so is used here. If the two known values are $\left(x_{1}, y_{1}\right)$ and $\left(x_{2}, y_{2}\right)$, then the $y$ value for some point is:

$y=y_{1}+\left(x-x_{1}\right) \frac{y_{2}-y_{1}}{x_{2}-x_{1}}$
Pearson's correlation was then employed to statistically analyse the correlation between the vegetation class and Gully/Open-Land class for every image collected within the study period. This reveals whether the continuous removal of vegetation is correlated with the development of Gully/Open Land found in the study area. All classes are then correlated with one another to determine all patterns.

\section{Pixel-based Unsupervised Classification}

Traditional per-pixel approaches deliver results for landform analysis that usually depend entirely on the information of individual pixels (Maglines et al., 2008). Only the spectral information is used for the classification. Other information, such as Blaschke, that implicitly exists within the data is not considered because according to Blaschke, as long as pixel sizes remained typically coarser than, or, similar in size to the objects of interest, emphasis will be placed on per-pixel analysis or sub-pixel analysis (Blaschke et al., 2014). Therefore, the main difference with traditional per-pixel approaches and utilizing an objectbased image analysis approach, is the explicit incorporation of neighborhood, distance and proximity parameters. 
For the study area of south-east Nigeria, land use classification was deduced from the raster data by ISO Cluster Analysis, a form of unsupervised classification. The number of classes used for unsupervised classification were 60 classes, 10 representing each band because there are 6 Landsat bands (Duke, 2012). This was assisted using the 100 land-cover points picked during field-work Table 1, which include 10 water bodies, 10 vegetation points, 10 Agricultural sites, 20 Urban-Land, 40 gully points and 10 open land points Fig. 5a. This was reclassified into 5 classes using level of inter-class similarities for the unsupervised approach.

Five classes were chosen to represent the land based on the Land-use/Land-cover types of the study area. The classes identified were 1. Water, 2. Vegetation, 3. Agriculture, 4. Urban-Land and 5. Gully/Open-Land. These were used to reclassify the ISO cluster classification Fig. 5b. Accuracy Assessment and validation of Field work points and pixel Landsat Classification gave $90 \%$ success Table 2.

\section{Object Based Image Supervised Classification (OBIA)}

As pixel-based classification approaches only rely on spectral per-pixel values, the idea of Object-Based Image Analysis (OBIA) enables the incorporation of additional analytical aspects, including geometry, broader context and more refined expert knowledge. According to (Blaschke, 2010) and (Aigbedion and Iyayi, 2007), OBIA produces relatively common regions, in regard to any homogeneity criterion. In recent years, OBIA has become a successful new methodology (Blaschke, 2010), that goes beyond the per-pixel approach. Although still using pixel information, through the grouping of pixels, additional features can be addressed such as the homogeneity of a region, within-region variation or differences to neighboring objects. The regions are typically generated through segmentation based on one or more criteria of homogeneity in one or more dimensions. In addition and sometimes of even greater advantage than the diversification of spectral value descriptions of objects, is the additional spatial information for objects (spatial topology, geometric descriptions).

Figure 5 considers each pixel as a separate object. Subsequently, adjacent pairs of image objects are merged to form larger segments. The merging decision is based on the local homogeneity criterion, describing the similarity between adjacent image objects. This was based on the 100 land-use/cover training samples Table 1 which was examined by looking at the histograms to check the normalization of training data as well as the pixel value ranges and check for overlap.

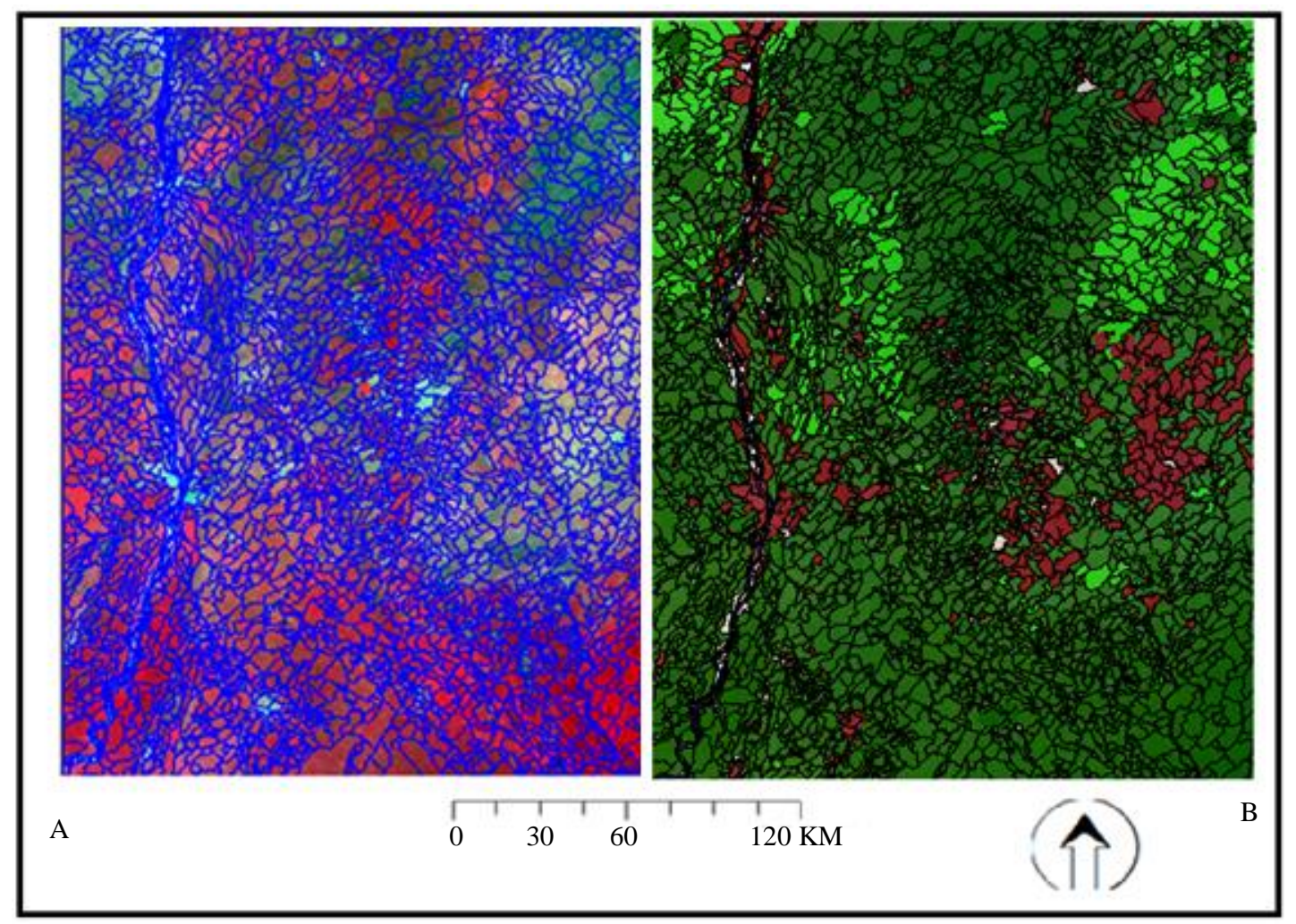

Fig. 5: (a) Year 2009 OBIA Image Segmentation of Landsat (b) shows result of object-oriented classification of Landsat of year 2009 image of the study area 
In trying to understand the effect of local environment on the gully sites and not simply the regional variations, the classified local environment of $10 \times 10 \mathrm{~km}$ area around each of the gullies were also used for both Pixel and OBIA classification to calculate the correlation between the classes. The central point of the gully was used as the centre of the $10 \times 10 \mathrm{~km}$ classified region helping to determine whether the same environmental variables are influencing gully development on both spatial scales. Accuracy Assessment and validation of Field work points and OBIA Landsat Classification gave 92\% success Table 3.

\section{Regional Land Cover Classification}

The classification methods for this purpose will be compared and contrasted". Many researchers have attributed landcover removal as the main source of gully development. In South East Nigeria, (Igwe, 2005; Onyekwere, 2001; Ijeoma and Okey, 2005) have separately agreed that gullies mostly develop on soil on which vegetal growth has been disturbed due to infrastructural developments, for example roads and housing developments. Land cover classification is one of the modern methods of ascertaining the level of landcover removal by human interference.

Pixel and Object Based Image Analysis (OBIA) land cover classification is conducted for the study region. Data is provided for each individual year within the defined study period. The regional study area measures approximately 57,758.034 $\mathrm{km}^{2}$. According to the two different classification methodologies, the results reveal that the vegetated land surface, at the beginning of the study in the year 1986, comprises $90 \%$ and $83 \%$ of the study area for Pixel and Object Based classification methods respectively. These values highlight the original dense canopy coverage of the region. By 2015, over a period of almost 30 years, this classified vegetated proportion of the total land surface has reduced to $35 \%$ according to Pixel based approaches and $41 \%$ for OBIA classification. According to both independent methodologies this highlights a significant loss in vegetated land surface. Losses of vegetated area are estimated at $55 \%$ and $41 \%$ of the total studied area, for Pixel and OBIA classification respectively, between 1986-2015. With respect to the regional land cover classification presented in Table 4 and 5 for each of the available study years, the significant loss in vegetation is predominantly attributable to increases in Urban-land and Agriculture. As well as appearing to contribute to a loss in vegetation these increases in urban and agricultural areas appear to have influenced the existence and development of Gully/Open-land formation in the study area. While a $55 \%$ reduction in vegetated land has been detected over the study period, other land use classes exhibit increases. The increases exhibited for the other classifications are 38\% (Urban), $13 \%$ (Gully) $0.4 \%$ (Water) and $3.6 \%$ (Agriculture) according to pixelbased classification, Table 4 . For the $41 \%$ reduction in vegetated land evident using OBIA classification over the study period, these classes account for increases of $31 \%$ (Urban), 10\% (Gully), $0 \%$ (Water), 0\% (Agriculture) Table 5. Both classification methods evidence the significant correlated increases of urban land cover and gully size.

\section{Gully/Open-Land Classification}

It is evident from the percentage changes that converse to the vegetation loss the Gully/open-land classification has followed a significant and steady increase in area covered over the same time period. According to pixel-based classification (Table 6a), the Gully/open-land class has increased from a proportionate land cover of $2 \%$ in 1986, to $15 \%$ in 2015 for Pixel and $4 \%$ in 1986 to $14 \%$ in 2015 for OBIA classification. This represents an increase in area size of gully/open lands of $13 \%$ and $10 \%$ for Pixel and OBIA classifications respectively over 30 years, Fig. 9a and 9b. A mean increase of $11.5 \%$.

The absolute values of area covered by the Gully/Openland class are shown in Table $6 \mathrm{a}$ and $6 \mathrm{~b}$ for Pixel and OBIA classification respectively. According to the Pixel classification an increase of 8974257-pixel count is exhibited during the study period. This equates to a mean annual increase of 299141.9 per year across the region. For the OBIA classification the value is 214043.1 per year Performing a simple two sample $t$ test of difference between the two groups of data show that there is no significant difference between the two classification methods and their accounts of the gully/openland class $(p=<0.05)$.

\section{Correlation of Regional Land-Covers}

The correlation between the pixel and OBIA count of vegetation, pixel and OBIA count of Gully/open-land development and Pixel and OBIA count of Urbanland is shown in Table 7 and therefore area of land-cover change is examined using Pearson's Correlation. The resulting coefficients for Vegetation against Gully/Openland are, Pixel based classification $\mathrm{r}=-0.971$ $(p<0.01)$ and OBIA classification $\mathrm{r}=-0.920(p<0.01)$ indicating a very strong negative correlation, emphasising the reducing vegetation levels and the 
increase in Gully/open-land development. Pixel and OBIA vegetation versus pixel and OBIA urbanland classification are $-0.976(p<0.01)$ and $-0.963(p<0.01)$ respectively, equally showing very strong negative correlation. Pixel and OBIA gully/openland versus pixel and OBIA urbanland show $0.962(p<0.01)$ and 0.887 $(p<0.01)$ respectively showing very strong positive correlations, over the study period 1986-2015. This is a very simple test but signifies that according to the chosen classification process vegetation land cover reduction, predominantly through anthropological activities, correlates with increases in open lands and gully development. It is good to point out here that some of these open lands could not revegetate because the land gets used by activities like mining, mineral exploration and exploitation and sand excavation activities. These deteriorate the land and allow gullies to set-in (Onyekwere, 2001; Valentin et al., 2005).

Table 1: 100 Land cover Reference points picked during field work for classification including 10 water bodies, 10 vegetation points, 10 Agricultural sites, 20 Urban-Land, 40 gully points and 10 open land points. Coordinates in Universal Transverse Mercator (UTM) $32 \mathrm{~N}$ in metres.

\begin{tabular}{|c|c|c|c|c|c|c|c|c|c|c|}
\hline \multirow[b]{2}{*}{1} & \multicolumn{2}{|l|}{ Water } & \multicolumn{2}{|l|}{ Vegetation } & \multicolumn{2}{|l|}{ Agriculture } & \multicolumn{2}{|l|}{ Urbanlands } & \multicolumn{2}{|c|}{ Gully/openlands } \\
\hline & Easting & Northing & Easting & Northing & Easting & Northing & Easting & Northing & Easting & Northing \\
\hline 2 & 249051.80 & 668301.08 & 242242.67 & 612665.61 & 313630.93 & 612977.27 & 258117.18 & 677498.35 & 279040.32 & 630127.83 \\
\hline 3 & 251728.02 & 674842.78 & 244253.75 & 636120.10 & 311748.20 & 597285.04 & 255287.40 & 679038.10 & 290963.48 & 672395.90 \\
\hline 4 & 248622.19 & 690974.92 & 263274.20 & 610116.70 & 285191.74 & 593573.81 & 255566.00 & 683415.95 & 283044.05 & 642487.15 \\
\hline 5 & 255669.06 & 690682.26 & 362306.96 & 623084.92 & 264435.22 & 625154.44 & 249066.23 & 684693.94 & 317475.49 & 627455.20 \\
\hline 6 & 255287.20 & 688135.79 & 334826.53 & 628112.91 & 241985.43 & 584011.35 & 248440.35 & 671230.06 & 323446.00 & 713518.00 \\
\hline 7 & 254920.40 & 631383.87 & 373144.22 & 694922.60 & 253881.57 & 599585.59 & 269436.39 & 665710.93 & 285272 & 649271 \\
\hline 8 & 300361.36 & 559809.56 & 415271.20 & 731544.55 & 259743.07 & 650627.86 & 285198.02 & 607294.05 & 279806 & 644590 \\
\hline 9 & 334974.77 & 532246.18 & 355263.52 & 628088.00 & 226561.18 & 661508.64 & 278506.70 & 606482.95 & 301901.00 & 620430.00 \\
\hline 10 & 290913.62 & 607951.48 & 341569.58 & 608975.99 & 235133.22 & 725631.48 & 316693.54 & 564932.77 & 392694.24 & 620722.95 \\
\hline 11 & & & & & & & 333739.87 & 610956.43 & 330452.05 & 705080.71 \\
\hline 12 & & & & & & & 370122.68 & 619696.68 & 259322.32 & 674641.62 \\
\hline 13 & & & & & & & 285428.59 & 686073.78 & 317475.49 & 627455.20 \\
\hline 14 & & & & & & & 287770.90 & 688388.04 & 277394.78 & 596903.36 \\
\hline 15 & & & & & & & 271846.27 & 663928.87 & 323245.00 & 713784.00 \\
\hline 16 & & & & & & & 338311.02 & 606044.64 & 285138.93 & 649246.3 \\
\hline 17 & & & & & & & 378839.87 & 595535.94 & 280062.58 & 685792.43 \\
\hline 18 & & & & & & & 287718.55 & 665973.35 & 283044.05 & 642487.15 \\
\hline 19 & & & & & & & 288989.72 & 665118.14 & 285607.00 & 633615.00 \\
\hline 20 & & & & & & & 323114.07 & 757361.93 & 323446.00 & 713518.00 \\
\hline 21 & & & & & & & & & 261516.24 & 632542.9 \\
\hline 22 & & & & & & & & & 328458.00 & 614902.00 \\
\hline 23 & & & & & & & & & 280062.58 & 685792.43 \\
\hline 24 & & & & & & & & & 285500 & 633512 \\
\hline 25 & & & & & & & & & 285633 & 633384 \\
\hline 26 & & & & & & & & & 285656 & 633251 \\
\hline 27 & & & & & & & & & 310800 & 628052 \\
\hline 28 & & & & & & & Openland & & 310821 & 628074 \\
\hline 29 & & & & & & & Easting & Northing & 310826 & 628045 \\
\hline 30 & & & & & & & 328458.00 & 614902.00 & 310928 & 628052 \\
\hline 31 & & & & & & & 237810.79 & 750349.61 & 330452.05 & 705080.71 \\
\hline 32 & & & & & & & 392694.24 & 620722.95 & 310528 & 620814 \\
\hline 33 & & & & & & & 266803.74 & 627071.18 & 294019 & 640235 \\
\hline 34 & & & & & & & 279184.92 & 629967.73 & 294015 & 640077 \\
\hline 35 & & & & & & & 233787.52 & 619482.15 & 293843 & 640186 \\
\hline 36 & & & & & & & 387224.82 & 633648.49 & 293895 & 640248 \\
\hline 37 & & & & & & & 236224.82 & 742358.14 & 259322.32 & 674641.62 \\
\hline 38 & & & & & & & 246492.69 & 785412.45 & 317475.49 & 627455.20 \\
\hline 39 & & & & & & & 311003.71 & 610305.22 & 277394.78 & 596903.36 \\
\hline 40 & & & & & & & 315576.62 & 608822.26 & 323245.00 & 713784.00 \\
\hline
\end{tabular}


Sylvanus Iro / American Journal of Environmental Sciences 2020, 16 (2): 34.47 DOI: 10.3844/ajessp.2020.34.47

Table 2: Accuracy Assessment and validation of field work points and pixel Landsat classification 2013 Field work

\begin{tabular}{lllllll} 
2013-pixel Landsat class & Water & Vegetation & Agric & Urbanland & Gully/openland & Raw Total \\
\hline Water & 9 & 0 & 0 & 0 & 1 & 6 \\
Vegetation & 0 & 8 & 2 & 0 & 2 & 12 \\
Agric & 0 & 2 & 8 & 0 & 0 & 10 \\
Urbanland & 0 & 0 & 0 & 19 & 1 & 20 \\
Gully/openland & 1 & 0 & 0 & 1 & 46 & 48 \\
Column Total & 10 & 10 & 10 & 20 & 50 & 100 \\
\hline
\end{tabular}

Overall Accuracy $=90 / 100=90 \%$

Table 3: Accuracy assessment and validation of field work points and OBIA Landsat classification

\begin{tabular}{|c|c|c|c|c|c|c|}
\hline \multirow[b]{2}{*}{2013 OBIA Landat class } & \multirow[b]{2}{*}{ Water } & \multicolumn{2}{|c|}{2013 Field work } & \multirow[b]{2}{*}{ Urbanland } & \multirow[b]{2}{*}{ Gully/openland } & \multirow[b]{2}{*}{ Raw Total } \\
\hline & & Vegetation & Agric & & & \\
\hline Water & 10 & 0 & 0 & 0 & 1 & 6 \\
\hline Vegetation & 0 & 8 & 2 & 0 & 1 & 11 \\
\hline Agric & 0 & 2 & 8 & 0 & 0 & 10 \\
\hline Urbanland & 0 & 0 & 0 & 19 & 1 & 20 \\
\hline Gully/openland & 0 & 0 & 0 & 1 & 47 & 48 \\
\hline Column Total & 10 & 10 & 10 & 20 & 50 & 100 \\
\hline
\end{tabular}

Overall Accuracy $=92 / 100=92 \%$

Table 4: Pixel based classification result as percentage of total area classified. Total area size $=0.57,758.034 \mathrm{~km}^{2}$

\begin{tabular}{|c|c|c|c|c|c|c|c|c|c|c|c|c|c|}
\hline & & '86 & 87 & '88 & 89 & '90 & '91 & '92 & '93 & '00 & '01 & '02 & '03 \\
\hline & Classes & $\%$ & $\%$ & $\%$ & $\%$ & $\%$ & $\%$ & $\%$ & $\%$ & $\%$ & $\%$ & $\%$ & $\%$ \\
\hline 1 & Water & 0.6 & 0.8 & 2 & 0.9 & 0.9 & 1 & 1 & 2.5 & 1 & 1 & 0.8 & 1 \\
\hline 2 & Vegetation & 90 & 90 & 76 & 75 & 72 & 70 & 64 & 62 & 59 & 59 & 57 & 52 \\
\hline 3 & Agriculture & 5.4 & 5.2 & 11 & 11 & 12 & 14 & 13 & 12.5 & 12 & 11 & 11.2 & 13 \\
\hline 4 & Urban-Lands & 2 & 2 & 8 & 9 & 10.1 & 10 & 15 & 16 & 17 & 18 & 20 & 22 \\
\hline \multirow{3}{*}{5} & Gully/openland & 2 & 2 & 3 & 4 & 5 & 5 & 7 & 7 & 11 & 11 & 11 & 12 \\
\hline & & ‘04 & '05 & ‘06 & '07 & '08 & '09 & ' 10 & '11 & '12 & '13 & '14 & ' 15 \\
\hline & & $\%$ & $\%$ & $\%$ & $\%$ & $\%$ & $\%$ & $\%$ & $\%$ & $\%$ & $\%$ & $\%$ & $\%$ \\
\hline 1 & Water & 1 & 3 & 1 & 1 & 3 & 2 & 3 & 3 & 3 & 1 & 1 & 1 \\
\hline 2 & Vegetation & 52 & 51 & 49 & 44 & 44 & 43 & 42 & 43 & 41 & 38 & 37 & 35 \\
\hline 3 & Agriculture & 13 & 10 & 14 & 14 & 10 & 10 & 10 & 9 & 9 & 9 & 9 & 9 \\
\hline 4 & Urban-Lands & 23 & 24 & 25 & 30 & 32 & 33 & 34 & 33 & 35 & 38 & 39 & 40 \\
\hline 5 & Gully/openland & 11 & 12 & 11 & 11 & 11 & 12 & 11 & 12 & 12 & 14 & 14 & 15 \\
\hline
\end{tabular}

Table 5: OBIA classification result as percentage of total area classified. Total area size $=57,758.034 \mathrm{~km}^{2}$

\begin{tabular}{|c|c|c|c|c|c|c|c|c|c|c|c|c|c|}
\hline & Classes & $\begin{array}{l}\text { '86 } \\
\%\end{array}$ & $\begin{array}{l}' 87 \\
\%\end{array}$ & $\begin{array}{l}\text { '88 } \\
\%\end{array}$ & $\begin{array}{l}\text { '89 } \\
\%\end{array}$ & $\begin{array}{l}\text { '90 } \\
\%\end{array}$ & $\begin{array}{l}\text { '91 } \\
\%\end{array}$ & $\begin{array}{l}\text { '92 } \\
\%\end{array}$ & $\begin{array}{l}\text { '93 } \\
\%\end{array}$ & $\begin{array}{l}00 \\
\%\end{array}$ & $\begin{array}{l}{ }^{\circ} 01 \\
\%\end{array}$ & $\begin{array}{l}{ }^{\prime} 02 \\
\%\end{array}$ & $\begin{array}{l}{ }^{\prime} 03 \\
\%\end{array}$ \\
\hline 1 & Water & 1 & 1 & 1 & 1 & 1 & 1 & 2 & 1 & 1 & 2 & 2 & 2 \\
\hline 2 & Vegetation & 83 & 80 & 76 & 75 & 73 & 71 & 71 & 68 & 61 & 59 & 57 & 56 \\
\hline 3 & Agriculture & 7 & 8 & 8 & 8 & 8 & 9 & 6 & 7 & 10 & 10 & 10 & 10 \\
\hline 4 & Urban-lands & 5 & 6 & 9 & 10 & 11 & 12 & 14 & 16 & 19 & 21 & 23 & 24 \\
\hline \multirow[t]{3}{*}{5} & Gully/openland & 4 & 5 & 6 & 6 & 6 & 7 & 7 & 8 & 9 & 8 & 8 & 8 \\
\hline & & ‘04 & ‘05 & ‘06 & ‘07 & ‘08 & ‘09 & ' 10 & '11 & '12 & '13 & ' 14 & ' 15 \\
\hline & & $\%$ & $\%$ & $\%$ & $\%$ & $\%$ & $\%$ & $\%$ & $\%$ & $\%$ & $\%$ & $\%$ & $\%$ \\
\hline 1 & Water & 2 & 2 & 2 & 2 & 2 & 2 & 2 & 2 & 2 & 2 & 1 & 1 \\
\hline 2 & Vegetation & 54 & 50 & 50 & 48 & 48 & 47 & 46 & 46 & 46 & 44 & 44 & 42 \\
\hline 3 & Agriculture & 9 & 9 & 9 & 9 & 8 & 8 & 8 & 8 & 7 & 7 & 7 & 7 \\
\hline 4 & Urban-lands & 26 & 29 & 29 & 30 & 32 & 33 & 33 & 32 & 33 & 34 & 35 & 36 \\
\hline 5 & Gully/openland & 9 & 10 & 10 & 11 & 10 & 10 & 11 & 12 & 12 & 13 & 13 & 14 \\
\hline
\end{tabular}


Table 6: (a) Calculated Pixel classification-based Area (pixel count) and \% covered by Gully/Openland class from 1986-2015 (red = interpolated). ( $\mathrm{red}=$ interpolated). Single pixel is equal to $900 \mathrm{~m}^{2}\left(57,758.034 \mathrm{~km}^{2}\right.$ total area)

\begin{tabular}{llllll}
\hline Years & Gully/openland pixel count & \% of Area covered & Years & Gully/openland pixel count & \% of Area covered \\
\hline 1986 & 1012176 & 2 & 2001 & 5616757 & 11 \\
1987 & 1012176 & 2 & 2002 & 5417067 & 11 \\
1988 & 1715029 & 3 & 2003 & 5741335 & 12 \\
1989 & 2210168 & 4 & 2004 & 5017688 & 11 \\
1990 & 2804669 & 5 & 2005 & 6389870 & 12 \\
1991 & 3200445 & 5 & 2006 & 7296029 & 11 \\
1992 & 3993673 & 7 & 2007 & 7423424 & 11 \\
1993 & 4790330 & 7 & 2008 & 6301827 & 11 \\
1994 & 4857860 & 7 & 2009 & 8024697 & 12 \\
1995 & 4966274 & 7 & 2010 & 7999151 & 11 \\
1996 & 5030673 & 8 & 2011 & 7367368 & 12 \\
1997 & 5132196 & 8 & 2012 & 8064697 & 12 \\
1998 & 5115838 & 8 & 2013 & 9276909 & 14 \\
1999 & 5297842 & 8 & 2014 & 9686547 & \\
2000 & 5263041 & 11 & 2015 & 9986433 & 15 \\
\hline
\end{tabular}

Table 6: (b) Calculated OBIA classification-based Area (pixel count) and \% covered by Gully/Openland class from 1986-2015 (red $=$ interpolated). Single pixel is equal to $900 \mathrm{~m}^{2}\left(57,758.034 \mathrm{~km}^{2}\right.$ total area)

\begin{tabular}{llllll}
\hline Years & Gully/openland pixel count & $\%$ of Area covered & Years & Gully/openland pixel count & $\%$ of Area covered \\
\hline 1986 & 2653360 & 4 & 2001 & 5344361 & 8 \\
1987 & 3679894 & 5 & 2002 & 5567043 & 8 \\
1988 & 3849040 & 6 & 2003 & 5938179 & 8 \\
1989 & 4124799 & 6 & 2004 & 6012407 & 9 \\
1990 & 4308708 & 6 & 2005 & 6680451 & 10 \\
1991 & 4676316 & 7 & 2006 & 6682816 & 10 \\
1992 & 4676526 & 7 & 2007 & 7348497 & 11 \\
1993 & 5344361 & 8 & 2008 & 5344361 & 10 \\
1994 & 5439796 & 8 & 2009 & 5344388 & 11 \\
1995 & 5426162 & 8 & 2010 & 7279418 & 12 \\
1996 & 5446288 & 8 & 2011 & 8016542 & 12 \\
1997 & 5516558 & 8 & 2012 & 8016752 & 13 \\
1998 & 5587394 & 8 & 2013 & 8684587 & 13 \\
1999 & 5743545 & 9 & 2014 & 8999346 & 14 \\
2000 & 6012406 & 9 & 2015 & 9074653 & \\
\hline
\end{tabular}

Table 7: Correlation results when correlating pixel vegetation count, OBIA vegetation count, Pixel Gully/openland count, OBIA Gully/openland count, Pixel Urbanland count, OBIA Urbanland count for each year of study period

\begin{tabular}{|c|c|c|c|c|c|c|c|}
\hline & & \multicolumn{6}{|l|}{ Correlations } \\
\hline & & Pixel__. & OBIA_. & Pixel__ & OBIA_ & Pixel_ & OBIA \\
\hline & & Vegetation & Vegetation & Gullyopenland & Gullyopenland & Urbanland & Urbanland \\
\hline & Sig. (2-tailed) & & 0.000 & 0.000 & 0.000 & 0.000 & 0.000 \\
\hline & $\mathrm{N}$ & 30 & 30 & 30 & 30 & 30 & 30 \\
\hline \multirow[t]{3}{*}{ OBIA_Vegetation } & Pearson Correlation & $0.981^{* *}$ & 1 & $-0.965^{* *}$ & $-0.920^{* *}$ & $-0.973^{* *}$ & $-0.963^{* *}$ \\
\hline & Sig. (2-tailed) & 0.000 & & 0.000 & 0.000 & 0.000 & 0.000 \\
\hline & $\mathrm{N}$ & 30 & 30 & 30 & 30 & 30 & 30 \\
\hline \multirow[t]{3}{*}{ Pixel_Gullyopenland } & Pearson Correlation & $-0.971^{* *}$ & $-0.965^{* *}$ & 1 & $0.897^{* *}$ & $0.962^{* * *}$ & $0.962^{* *}$ \\
\hline & Sig. (2-tailed) & 0.000 & 0.000 & & 0.000 & 0.000 & 0.000 \\
\hline & $\mathrm{N}$ & 30 & 30 & 30 & 30 & 30 & 30 \\
\hline \multirow[t]{3}{*}{ OBIA_Gullyopenland } & Pearson Correlation & $-0.892^{* *}$ & $-0.920^{* *}$ & $0.897^{* *}$ & 1 & $0.887^{* *}$ & $0.887^{* *}$ \\
\hline & & Sig. (2-tailed) & 0.000 & 0.000 & 0.000 & & 0.000 .000 \\
\hline & $\mathrm{N}$ & 30 & 30 & 30 & 30 & 30 & 30 \\
\hline \multirow[t]{2}{*}{ Pixel_Urbanland } & Pearson Correlation & $-0.996^{* *}$ & $-0.973^{* *}$ & $0.962^{* *}$ & $0.887^{* *}$ & 1 & $1.000^{* *}$ \\
\hline & Sig. (2-tailed) & 0.000 & 0.000 & 0.000 & 0.000 & & 0.000 \\
\hline & Sig. (2-tailed) & 0.000 & 0.000 & 0.000 & 0.000 & 0.000 & \\
\hline & $\mathrm{N}$ & 30 & 30 & 30 & 30 & 30 & 30 \\
\hline
\end{tabular}




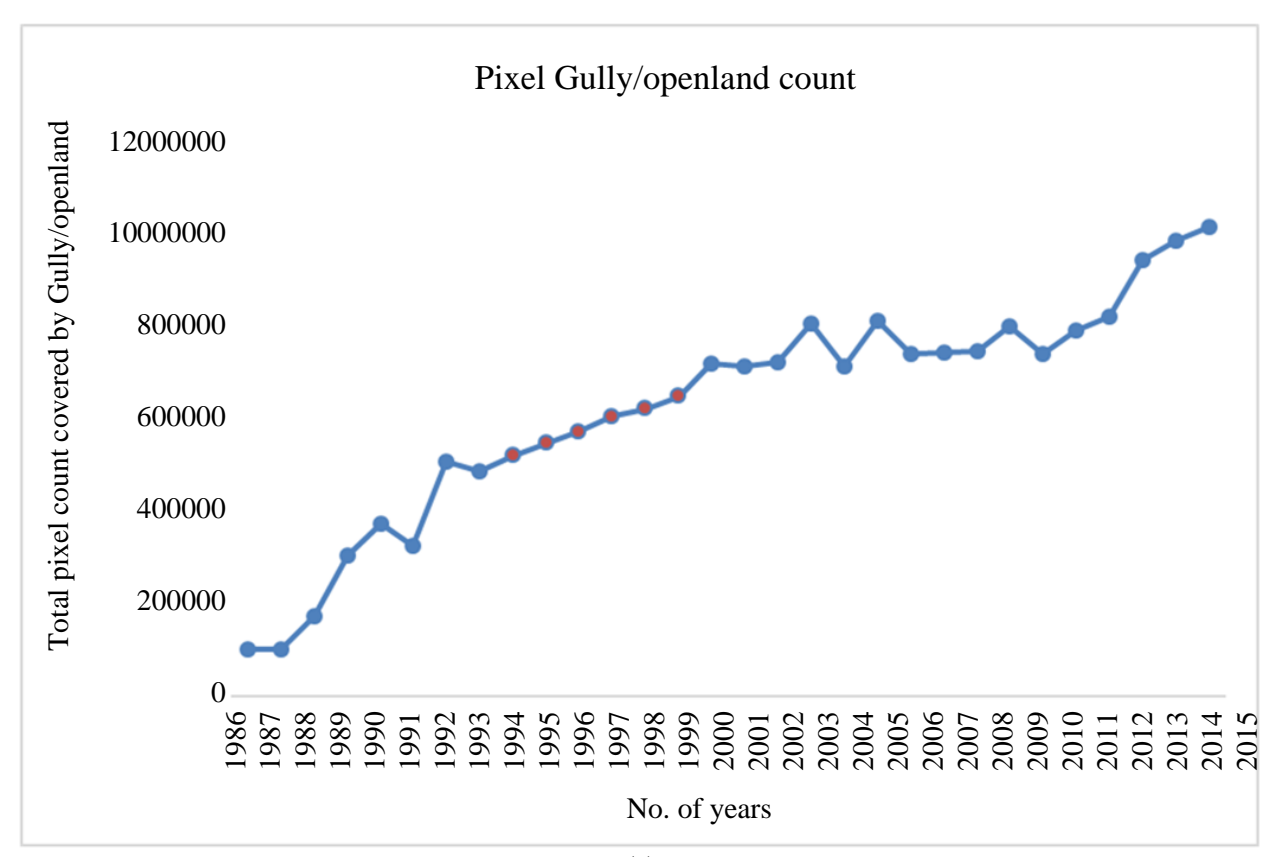

(a)

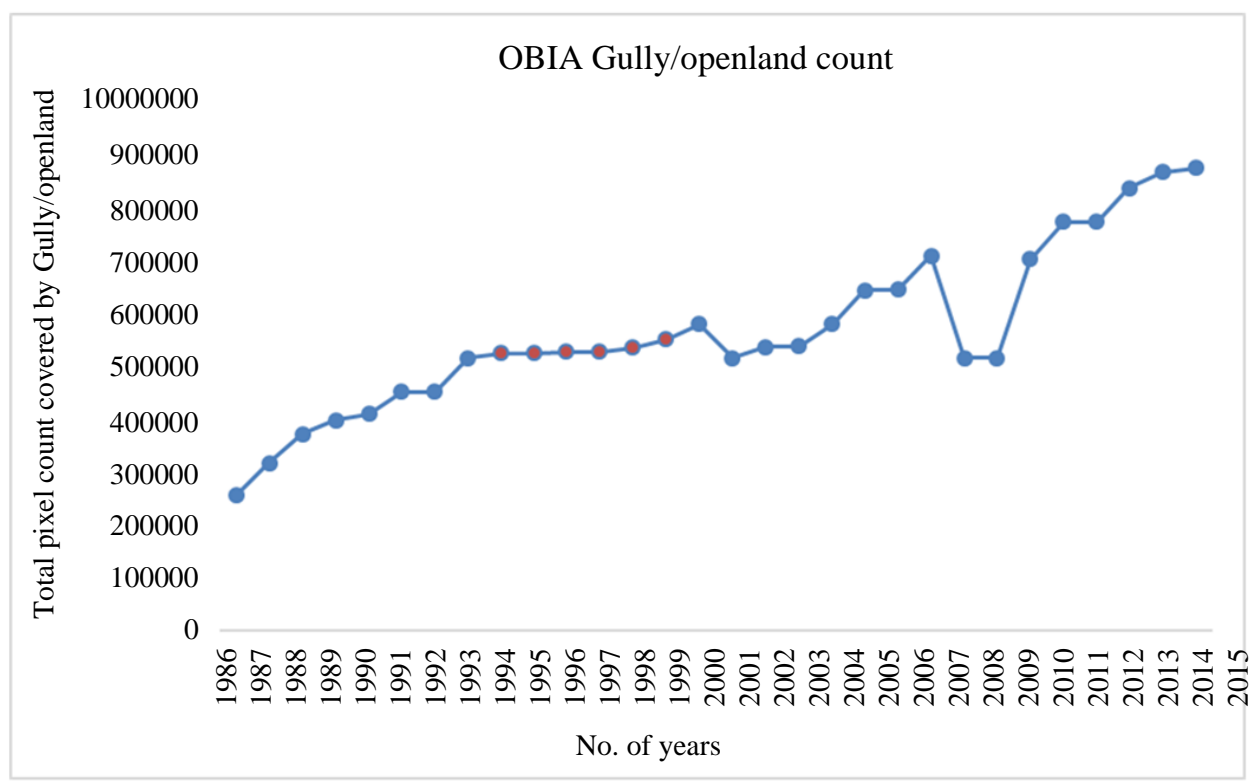

(b)

Fig. 9: (a) (Top) Pixel based (pixel count) change over time of Gully/open land showing from 1986 to 2015 (observed images are in blue circle points while interpolated points are in red circle points). (b): (Bottom) OBIA Area changes over time of Gully/open land. Pixel size is equivalent to $300 \mathrm{~m}^{2}$

Similar correlation analyses with the other 2 classes showed that the resulting correlation between Vegetation and Urban land were $r=-0.9$ and $r=-0.9$ for Pixel and OBIA classification respectively. Values of $r=-0.9$ and $r=$ -0.2 for pixel and OBIA classification respectively show a very strong negative correlation and a weak negative correlation respectively between Agriculture land increase and vegetation loss. The difference between the two values could be the different ways OBIA and pixel do classification, it could be that some of the vegetation area that were classified as Agric land in pixel, while OBIA separated it and placed it under agric land. This could be through pixel grouping and homogeneity of a region (Li et al., 2004). 


\section{Discussion}

Correlation analyses examining the relationship between vegetation area and the occurrence of Gully/open-land development was examined in the results section using Pearson's and where necessary Spearman's, correlation coefficients Table 7. The analysis was conducted for both the OBIA and Pixel based classification methodologies incorporated in this study within a broader analysis of land cover change in the study area. In terms of the correlation between vegetation area and gully/openland development, Pixel based classification produced a correlation of $r=-0.9$ $(p<0.05)$. A similar strength of correlation was exhibited for OBIA with $\mathrm{r}=-0.9 \quad(p<0.05)$ with both results indicating a very strong and significant negative correlation between the amount of vegetated area and Gully/open-land development over the study period 1986-2015. Although such a strong and apparent correlation is evident and fundamentally expected, what cannot be conclusively determined from the analysis is whether the vegetation loss had a causal effect on gully development. Based on the correlation levels and from referring to studies such as (Egboka, 1993; Nyom, 2005; Posser and Slade, 1994; Madu et al., 2006; Igbozurike, 2010) the causal effect is highly probable. These referenced studies from different time periods and regions agreed that the removal of vegetation begins a detrimental series of events which affect soil quality and stability which then directly result in gully development.

The vegetation land cover reduction exhibited on the regional scale in this study, across approximately $57,758 \mathrm{~km} 2$, is predominantly enacted through anthropological activities, Table 4 and 5, with anthropogenic landcovers inversely related with vegetation cover. Similar correlation analyses undertaken with the other landuse classes showed that the resulting correlation between Vegetated area and Urban-land increase were $r=-0.5$ and $r=-0.9(\mathrm{P}<0.05)$ for Pixel and OBIA classifications respectively, showing reasonably strong negative associations. The increasing level of urban area exhibits very strong correlation with a decreasing area of vegetation particularly for the OBIA classification approach. Values of $\mathrm{r}=-0.9$ and $\mathrm{r}=-0.2$ $(P<0.05)$ for pixel and OBIA classification respectively show a very strong negative correlation and a weak negative correlation respectively between Agricultural land area and vegetated area showing similar advances for these classes as vegetated area reduced. The largely differing correlation coefficients associated with the agricultural landuse could be as a result of the methodology OBIA method uses in classification through grouping similar pixels of agricultural areas into vegetation areas or vice versa (Blaschke, 2010). Okpara has reported that some cities such as Onitsha and Nnewi,
Owerri and Orlu, Enugu and Nite Mile in southeast Nigeria have formed conurbations because of population pressure, resulting in a loss of rich rainforest vegetation (Madu et al., 2006). Nigeria itself has the 9th largest urban population in the world therefore pressures on the land in habitable areas can be extreme (Maglines et al., 2008). This urban expansion is therefore a likely reason why urban areas have continuously increased while vegetation is reducing as a consequence. The urban expansion also has the added dimension of being largely unregulated and this is believed to be where significant drivers for gully erosion are arising. Igbozurike notes that about 600 buildings that are erected in Owerri, Awka, Aba and Onitsha as a consequence of vegetation removal do not possess the required planning permissions (Igbozurike, 2010). This unregulated expansion is therefore a contributor to environmental issues, for example blocking natural water runoff courses and channels. This can lead to severe land degradation and gully erosion. This was discovered by Okocha, that some gully erosion going on at Okigwe, Umuahia, Onitsha and Enugu urban centres in southeast Nigeria resulted from buildings being built across topographic contours, runoff channels and areas prone to gully devastation (Okoro and Nweke, 2013). Therefore, the problem is not the population but the relationship to the environment, as pointed out by (Castillo and Gomez, 2016).

Within the study region, according to the tested classification methods, Table 4 and Table 5, the level of vegetation area has reduced during the study period from 90\% (Pixel) and 83\% (OBIA) in 1986 to 35\% (Pixel) and $42 \%$ (OBIA) in 2015. These percentages are taken from a total area of $57,758.034 \mathrm{~km}^{2}$. Correlating the year on year regional changes in landcover with the changing individual gully sizes, shows that the area of each gully and hence its change in this metric is negatively correlated with vegetation area in the region. From the analysis of all surveyed gullies independently with the landscape on a local scale, $(10 \mathrm{~km}$ by $10 \mathrm{~km}$ centred on gully), they were generally shown to exhibit a very strong negative correlation between vegetation area and gully/openland area. This was shown in all cases for both pixel and OBIA vegetation classes. Based on the correlation, the study area has consistently shown a reduction in areas of vegetation resulting in increasing levels of gully/openland as denoted by a negative correlation on both the regional and local scale. These examples largely vindicate the use of both classification methods as a quality control. The strong negative correlation reported means that vegetation, or more precisely the removal of vegetation is very likely contributing to gully development in a direct or indirect manner (Madu et al., 2006). 


\section{Conclusion}

Determining Causes of Gully Erosion and Associated Rates of Change in South-East Nigeria, using a Remote Sensing and GIS Methodology, was conceived out of the numerous gully developments, inaccessibility to some and the helplessness of the communities in finding solutions to the rampant problem in southeast Nigeria. The field work was carried out in southeast Nigeria and the rest of the developmental research was carried out at the University of Brighton. The research work analysed the topography, the land-cover satellite images for a period of 30 . This long period of data collection and analysis provided enough information on what has been happening in the past and the anthropogenic activities that are responsible for gully development. The gullies studied, were traced and tracked from 1986-2015 (30Yrs period). This was primarily to observe their relationship with landcover of the study area. It was observed from the analysis that as the vegetation of the study area continues to reduce, open lands and gullies continue to develop while new gullies are expected to form. The open land development that was tied to vegetation loss could be responsible for the gully development as can be found from the location of gully points overlaid on classified satellite images. In general, the tracking and tracing of the gully sites showed that their occurrence and development positively correlated with vegetation removal for the 30 years' period. Exceptions were found in some year(s) when gullies were being tackled by communities, ministries and agencies to reduce or stop development.

\section{Recommendation}

As a result of the findings of this study, 3 key recommendations are offered to help in future to mitigate gully formation, generation and development in southeast Nigeria and potentially in any region having similar environmental problems:

1. Retention and infiltration of surface water should be provided in areas where runoff is high to avoid high runoff which erodes the soil from upland. Therefore, since slope, gradient and elevation is natural and cannot be changed, the retention and infiltration of runoff will be very important

2. Proper land-management practices must be employed to prevent forest fires and illegal wood logging and to avoid openlands development which can evidently lead to gully development. If the vegetal covers are allowed, it may lead to soil stabilisation, rainfall runoff retention and also control the already developed gullies but may not curb their progress entirely
3. Control of urbanlands (road construction, building structures and mining) which can reduce the effect on soil and vegetation removal to avoid gully development. Since urban development is tied on the use and removal of physical environment and mining which helps to create openlands, it can be reduced and controlled, which will reduce the level of gully formation and development

\section{Acknowledgement}

University of Brighton, UK and Imo State University, Owerri Nigeria

\section{Ethics}

The study was done by me (Dr Sylvanus Iro) with no grant from any agent or foundation. This work was carried out as my way of contribution to providing solution to incessant gully development in southeast Nigeria under research standard of Imo State University, Owerri southern Nigeria

\section{References}

Abdulfatai, I.A., I.A. Okunlola, W.G. Akande, L.O. Momoh and K.O. Ibrahim, 2014. Review of gully erosion in Nigeria: Causes, impacts and possible solutions. J. Geosci. Geomat., 2: 125-129.

Aigbedion, I. and S.E. Iyayi, 2007. Environmental effect of mineral exploitation in Nigeria. Int. J. Phys. Sci., 2: 033-038.

Blaschke, T., 2010. Object based image analysis for remote sensing. ISPRS J. Photogramm. Remote Sens, 65: 2-16. DOI: 10.1016/j.isprsjprs.2009.06.004

Blaschke, T., G.J. Hay, M. Kelly, S. Lang and P. Hofmann et al., 2014. Geographic object-based image analysis-Towards a new paradigm. ISPRS J. Photogramm. Remote Sens, 87: 180-191.

DOI: $10.1016 /$ j.isprsjprs.2013.09.014

Castillo, C. and J. Gomez, 2016. A century of gully erosion research: Urgency, complexity and study approaches. Earth Sci. Rev., 160: 300-319. DOI: 10.1016/j.earscirev.2016.07.009

Chigbu, P., H.U. Okonkwo and M.M. Nwagwu, 2011. Erodibility in relation to soils of southeast Nigeria. Land Manage., 13: 86-97.

Duke, M., 2012. Erosion and Depositions in Akamkpa Cross River State, Nigeria Environmental Society Team Nigeria.

Egboka, B.C.E., 1993. The raging war: A publication of anambra state government of Nigeria, Awka.

Elmahboub, W., F. Scarpace and B. Smith, 2009. A highly accurate classification of TM data through correction of atmospheric effects. Remote Sens., 1: 278-299. DOI: 10.3390/rs1030278 
Ezezika, O.C. and O. Adetona, 2011. Resolving the gully erosion problem in Southeastern Nigeria. J. Soil Sci. Environ. Manage., 2: 286-291.

Gao, Y., J.F. Mas, I. Niemeyer, P.R. Marpu and J.L. Palacio, 2007. Object-based image analysis for mapping land-cover in a forest area. Universidad Nacional Autónoma de Mexico.

Gayawan, E., A. Ekundayo and S.B. Adebayo, 2014. Possible determinants and spatial patterns of anaemia among young children in Nigeria: A Bayesian semi-parametric modelling. Int. Health, 6: 35-45. DOI: 10.1093/inthealth/iht034

Igbozurike, K.H., 2010. Characterisation of gully formed in valley areas of southeast Nigeria. Pearce pub. Limited, Awka.

Igwe, 2005. Erodibility in relation to water-dispersible clay for some soils of eastern Nigeria. Land Degradat. Dev., 16: 87-96. DOI: 10.1002/ldr.647

Ijeoma, F. and U.N. Okey, 2005. Soil degradation assessment in Southeastern Nigeria. Erosion Processes Quantified Nigeria Geographic, 23: 51-63.

Li, W., C.J. Rehmeyer, C. Staben and M. Farman, 2004. Terminus -telomeric end-read mining in unassembled sequences. University of Kentucky, Lexington.

Madu, F.H., G.M. Okaro and W.L. Uko, 2006. Role of vegetation in the control of water erosion in okigwe. Nigeria Soil Erosion, 1: 22-32.

Maglines, R.G., M.C. Laurence, S. Cosmpendio, A. Mitch Allan and B.H.B. Michael et al., 2008. Rulebased classification of agricultural resources through object-based image analysis using lidar derivatives and orthophoto: The case of tabontabon. Visayas State University, Philippines.

Nyom, 2005. Soil erosion management and control in baminda southern Cameroun. Land Manage. J., 1: 7-17.

Obiadi, I.I., C.M. Nwosu, N.E. Ajaegwu, E.K. Anakwuba and N.E Onuigbo et al., 2011. Gully erosion in anambra state, South East Nigeria: Issues and solution. Int. J. Environ. Sci.
Okonkwo, E., 2014. Traditional methods of preserving dead human bodies in Southeastern Nigeria.

Okoro, C. and J. Nweke, 2013. Problems in Southeast Nigeria. Cape publishers, Owerri Nigeria.

Oltmanns, S., I. Marzolff, D. Tiede and T. Blaschke, 2014. Detection of gully-affected areas by applying Object-Based Image Analysis (OBIA) in the Region of Taroudannt, Morocco.

Onyekwere, J.K., 2001. The effect of human impact on ground cover and subsequent erosion in southeast Nigeria. Environ. Res., 3: 55-63.

Poesen, J. and C. Valentin, 2003. Gully erosion and global change. Proceedings of the 1st International Symposium on Gully Erosion, (SGE' 03) Leuven, Belgium, pp: 87-562. DOI: $10.1016 / \mathrm{S} 0341-8162(02) 00143-1$

Posser, I.P. and C.J. Slade, 1994. Gully formation and the role of valley floor vegetation. South-Eastern Australia Geol., 22: 1127-1130. DOI: 10.1130/00917613(1994)022<1127: GFATRO>2.3.CO;2

Rozenstein, O. and A. Karniel, 2011. Comparison of methods for land-use classification incorporating remote sensing and GIS Inputs.

Valentin, C., J. Poesen and Y. Li, 2005. Gully erosion: Impacts, factors and control. Sci. Direct. Catena, 63: 132-153. DOI: 10.1016/j.catena.2005.06.001

Virginia, G., 2011. Virginia view - digital atlas of Virginia.

Vrieling, A., S.C. Rodrigues, H. Bartholomeus and G. Sterk, 2007. Automatic identification of erosion gullies with ASTER imagery in the Brazilian Cerrados. Int. J. Remote Sens., 28: 2723-2738. DOI: $10.1080 / 01431160600857469$

$\mathrm{Wu}$, Y. and H. Cheng, 2005. Monitoring of gully erosion on the Loess Plateau of China using a global positioning system. Catena, 63: 154-166. DOI: 10.1016/j.catena.2005.06.002w 